\section{Creationist appeal told that Ark claims 'were scientific'}

[SYDNEY] A Sydney court was told last week that public lectures by Bible church elder Allen Roberts on his claims that he had found evidence for the existence of Noah's Ark in Turkey were scientific, not religious, in character, and should be judged as such.

David Bennett QC was presenting an appeal before three judges in the Federal Court of Australia on behalf of Ian Plimer, a professor of geology at the University of Melbourne. Plimer had accused Roberts of misleading or deceptive conduct towards consumers, an offence for people in business.

The original trial judge, Ronald Sackville, had found Roberts was wrong in his scientific claims and would have breached fair trade acts if he had acted in trade; his verdict was that this was not proven (see Nature 387, 540 \& 837; 1997). Sackville also said that publicity surrounding the case presented it as a conflict between science and religion, but resolving such matters had no place in court.

After the court hearing, Plimer said he had used his "last shred" of money to finance the appeal and would go bankrupt if he loses. Judgement is expected by the end of the year.

Bennett, who was not involved in the earlier trial, claimed that Sackville had erred in drawing various conclusions under the Fair Trading Acts of the various Australian states and the federal Trade Practices Act.

Summarizing evidence which he claimed proved that Roberts and supporters in the Noah's Ark Research Foundation (NARF) had acted in trade or commerce when selling tickets, tapes and publications, Bennett said the goal had been to raise $\mathrm{A} \$ 1.95$ million (US\$1.4 million) to investigate the site of the supposed remains of the Ark.

Malcolm Duncan, a barrister acting for Roberts, described Plimer's claim that Roberts was acting in trade or commerce as "fundamentally silly" as it "would make the sale (whether for profit or not) of any religious tract actionable under the Fair Trading Acts".

Challenged by Judge Catherine Bransden, Duncan appeared to concede that NARF was in trade. Bennett claimed this as support for the appeal, but the presiding judge, John Davies, did not see it as a concession.

After the original verdict, Roberts claimed that Sackville's verdict "preserved the free speech of anyone who has something important to say publicly". He did not attend the appeal hearing.

Roberts had originally sued Plimer for defamation after expelling him and other geologists from his 1992 lectures for trying to ask questions. This case has yet to be heard. Plimer said he pursued his present action to forestall the libel suit.

PeterPockley

\title{
Scientists criticize review of Indian research institute
}

[NEW DELHI] A proposal by an international review committee that the Tata Institute of Fundamental Research (TIFR) in Bombay (now Mumbai) should streamline its administration and restructure its research so as to become globally competitive has been sharply criticized by some faculty members, who say it was a rushed job.

The institute was set up by the late Homi Bhabha in 1945. It became a launch pad for India's space and atomic energy programmes, as well as catalysing the growth of its electronic and computer industry. Bhabha also created groups in radioastronomy and computer science which had creditable successes - India's first electronic computer was built at TIFR in the 1960s.

But the country's leading science institute has recently been in the news for less estimable reasons - such as plagiarism by a senior faculty member - and its international reputation has slipped. This prompted its council of management to seek advice from experts abroad.

The review committee was headed by Lord Porter, Nobel prizewinner and past president of the Royal Society, now at Imperial College, London. Other members were Sir Arnold Wolfendale, former Astronomer Royal and president of the Royal Astronomical Society, now at the University of Durham, UK; David Mumford, president of the International Mathematical Union, now at Brown University, Rhode Island; Sydney Brenner of the Molecular Science Research Institute, La Jolla, California; and B. V. Sreekantan, previous director of TIFR.

M. G. K. Menon, a former TIFR director and now a member of TIFR's council of management, admits that the committee's five-day review period in January might have been too short, but says that it had nevertheless done a fine job.

But the report, which was released this month, while being generally complimentary about the state of research, has evoked mixed reactions. "In general, we welcome the report, even though some faculty members are unhappy," says Sudanshu Jha, who has headed the institute since July 1997, and who hopes that the recommendations will help him in his plans to "rebuild" TIFR.

Jha declines to comment, however, on the committee's controversial suggestion that TIFR should give up nuclear energy research and transfer its only accelerator facility - the pelletron - to the Bhabha Atomic Research Centre. The committee recommends that research in solid-state physics, radioastronomy, computer science and molecular biology should be augmented. The institute's high-

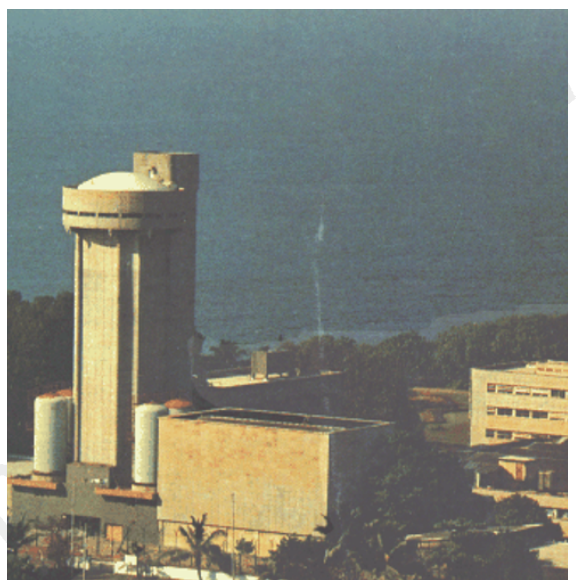

Tata institute: abandon nuclear energy research and transfer its accelerator, the review proposes.

energy research programme, though insignificant in world terms, "should continue", but the astronomy programme should be reduced.

The work of the pure mathematics group came in for praise. But a suggestion that the theoretical computer group be merged with pure and applied mathematics has provoked strong opposition. The committee withdrew a similar idea to merge the molecular biology group in Mumbai with TIFR's National Centre for Biological Sciences in Bangalore, after some faculty members threatened to resign rather than move from Mumbai.

In response to the institute's constant complaint of inadequate funding, the committee suggests that it enlist the help of foundations, rather than seek government support, and also increase the commercial exploitation of research results. Although fundamental research is TIFR's main role, it said, the "application of research results to national needs should not be ignored".

The committee also asked the management council to set up a panel to examine staff promotion policy and the possibility of a recruitment drive worldwide. It described the shortage of people joining the institute as "surprising and worrying". Menon claims that TIFR has already set up a group to revamp the administration and to look into promotion and recruitment policies.

"The report is not a court order," says Jha, who has distributed copies to all staff, asking for their comments. "Whatever suggestion is practical, we will implement."

But Nataraja Sarma, a nuclear physicist associated with TIFR for 35 years, says that two earlier internal reviews produced no improvement, and that entrenched interests in the institute could mean that although "the present review is reasonable, no serious changes will ensue".

K.S.Jayaraman 